\title{
Comparison of the application of elastic bandage and medical tape in pain reduction in primary and secondary teachers
}

\author{
Comparação da aplicação de bandagem elástica e esparadrapo na redução da dor em \\ professores de ensino fundamental e médio
}

Debora Mottin ${ }^{1}$, Cássio Preis ${ }^{1}$, Luiz Bertassoni Neto ${ }^{1}$

DOI 10.5935/2595-0118.20180064

\section{ABSTRACT}

BACKGROUND AND OBJECTIVES: The convolutions generated on the patient's skin with the application of the elastic bandage reduce the pressure on the mechanoreceptors and thus, the nociceptive stimulus. The objective of this study was to compare the effect of the elastic bandage application with the application of the medical tape in myofascial pain in the region of the upper fibers of the trapezius muscle in teachers.

METHODS: Participants were assessed using the McGill-Melzack Pain questionnaire and the numeric pain rating scale, palpation for the detection of trigger points, goniometry for shoulder abduction and lateral neck flexion, and the upper trapezius muscle strength test. Participants were randomly divided into two groups. In the first moment, the participants of group A received an application of elastic bandage, with the "Y" technique, and those belonging to group $B$ received the application of the same technique, however, using the medical tape. Both groups were reassessed after teaching class and after 24 hours. Two weeks later, there was the inversion of the materials used.

RESULTS: The sample consisted of 16 teachers. Group A had a significant statistical pain reduction, according to the numeric pain rating scale, between the initial assessment and post-application at the first moment $(\mathrm{p}=0.00)$ and at the second moment $(p=0.02)$. A similar result was found in group $B$, according to the numeric pain rating scale, both at the first moment $(\mathrm{p}=0.01)$ and at the second moment $(p=0.03)$. In both groups, there was pain attenuation with no significance on the effect of the elastic bandage or the medical tape.

CONCLUSION: The application of elastic bandage has the same effect that the medical tape in reducing pain.

Keywords: Faculty, Myofascial pain syndromes, Pain, Physical therapy, Physical therapy modalities.=

1. Pontifícia Universidade Católica do Paraná, Departamento de Fisioterapia, Curitiba, PR, Brasil.

Submitted on May 01, 2018.

Accepted for publication on September 17, 2018.

Conflict of interests: none - Sponsoring sources: none.

Correspondence to:

Rua Zacarias de Paula Xavier, 221 - Centro

83414-160 Colombo, PR, Brasil.

E-mail: dehmottin@hotmail.com

(c) Sociedade Brasileira para o Estudo da Dor

\section{RESUMO}

JUSTIFICATIVA E OBJETIVOS: As circunvoluçôes geradas na pele do paciente com a aplicação da bandagem elástica reduzem a pressão dos mecanorreceptores e assim, o estímulo nociceptivo. $\mathrm{O}$ objetivo deste estudo foi comparar o efeito da aplicação da bandagem elástica com a aplicação de esparadrapo na dor miofascial na regiāo das fibras superiores do músculo trapézio de professores. MÉTODOS: Os participantes foram avaliados através do questionário da dor de McGill-Melzack e a escala numérica, palpação para detecção de pontos-gatilho, goniometria de abduçáo do ombro e láteroflexáo de cervical e teste de força no músculo trapézio superior. Aleatoriamente foram divididos em dois grupos. No primeiro momento, os participantes do grupo A, receberam a aplicação de bandagem elástica, com a técnica em "Y" e, os pertencentes ao grupo $\mathrm{B}$, receberam a aplicação da mesma técnica, entretanto com esparadrapo. Ambos os grupos foram reavaliados após ministrar aula e após 24 horas. Duas semanas após, ocorreu a inversão dos materiais utilizados.

RESULTADOS: A amostra foi constituída por 16 professores. O grupo A apresentou redução estatisticamente significativa da dor na escala numérica entre a avaliação inicial e pós-aplicação no primeiro momento $(\mathrm{p}=0,00)$ e no segundo momento $(\mathrm{p}=0,02)$. Resultado semelhante foi encontrado no grupo B na escala numérica, tanto no primeiro momento $(\mathrm{p}=0,01)$ quanto no segundo momento $(\mathrm{p}=0,03)$. Em ambos os grupos a dor atenuou sem haver significância para o efeito da bandagem elástica ou esparadrapo.

CONCLUSẪ: A aplicação de bandagem elástica apresenta o mesmo efeito da aplicação de esparadrapo para a reduçâo do quadro álgico.

Descritores: Dor, Fisioterapia, Modalidades de fisioterapia, Professores, Síndromes da dor miofascial.

\section{INTRODUCTION}

The myofascial pain syndrome is a muscular condition caused by trigger points (TP), attributed to repetitive effort, maintenance of incorrect postures, musculoskeletal disorders, systemic diseases, sedentary lifestyle, and sleep disorders ${ }^{1,2}$.

Teachers constitute an occupational group with a high prevalence of musculoskeletal pains. The causes are multifactorial. Among them are the intense physical effort, inadequate furniture, and long working hours. It is also associated with psychosocial factors, such as high level of stress, low social support, and professional satisfaction ${ }^{3,4}$. 
The treatment of myofascial pain includes the Kinesiotaping method, which uses an elastic bandage $(\mathrm{EB})^{5,6}$. Originally developed in Japan by Kase, it has become more and more popular ${ }^{7}$ over the years ${ }^{7}$.

The elastic bandage expands up to $140 \%$ of its natural size, thus matching the skin elasticity, with its thickness and weight also being comparable. The bandage is also hypoallergenic and water resistant. Equally important is that it does not contain drugs, and all the reported benefits come from the elasticity of the material ${ }^{8}$. The EB effects are not fully elucidated. This method proposes analgesia, improvement of the muscle function via muscle tone regulation, to help the joint function, eliminate blockages in the bloodstream, and help lymphatic drainage. The studies show that it is effective when applied isolatedly. This fact can be associated with the placebo effect. When combined with the physical therapy, presumably the ideal method of treatment, there was no meaningful difference ${ }^{7,9-13}$. The combination of the EB expansion capacity and the application over the elongated muscle creates circumvolutions on the patient' skin when it returns to the neutral position. These circumvolutions reduce the pressure on the mechanoreceptors located below the dermis, thus decreasing the nociceptive stimulus $^{14,15}$. These circumvolutions also increase the space between the skin and the muscle, improving blood and lymphatic flows ${ }^{16}$. There is evidence that the pain is partially mediated by an endogenous mechanism of the brain, called the medial nociceptive system, which can contribute to the emotional component of pain. This system can be influenced by the patient's expectations which, in turn, reduce the pain through the descendent inhibition and release of opioids. These results suggest that a placebo has a true physiological effect ${ }^{17}$.

If the $\mathrm{EB}$ indeed acts inhibiting the descending pathway or another similar mechanism, it is possible that the application of medical tape provides enough stimulus to have a therapeutic effect regarding the reduction of the pain ${ }^{14}$.

The purpose of this study was to compare the effect of the EB application with the medical tape application in myofascial pain in the region of the upper fibers of the trapezius muscle of teachers.

\section{METHODS}

Applied, experimental, qualitative, quantitative, and descriptive research conducted from March to June 2015, with teachers from four schools of the public and private education system, located in the metropolitan area of Curitiba.

Female teachers with TP and pain complaints in the region of the upper fibers of the trapezius muscle were included, aged from 20 to 50 years, who have been working for at least two years and at least 25 hours per week. The exclusion criteria were pregnancy, participants allergic to the medical tape, and with diseases in the EB application area. One participant who had supraspinatus muscle tendonitis and two above the age group were excluded. All volunteers were informed about the performed procedures and signed the Free and Informed Consent Form (FICT).

The sample calculation was based on the assumption that for populations with more than 150 people the sample should be of $10 \%$, and for populations with less than 150 people, 20\%. Knowing that there is an average of 80 teachers and that it is not the totality with the required characteristics, the minimum sample for the study was of 16 participants, who represent $20 \%$ of the population.

The participants were divided according to the order they were evaluated; the first evaluated was sent to group $\mathrm{A}$, the second to group $\mathrm{B}$, and so forth. The participants were identically evaluated during the breaks between classes. The personal information was collected (age, weight, height, marital status). In the patient's history, the main complaint was investigated, as well as information on the professional activity, and the history of pain using the McGill-Melzack Pain Questionnaire ${ }^{18}$ and the numeric scale (NS). The TP was identified by the palpation as a circumscribed point that is presented spontaneously or by acupressure, hypersensitivity, taut band, and referred pain. The Goniometer Pro Preview program was used to measure the range of motion (ROM) of the cervical lateral flexion, installed in a Samsung S5 Galaxy Smartphone. With the participant sitting, head in a neutral position, the device was positioned on the spinous process of the seventh cervical vertebra to establish the articular $0^{\circ}$ and then the desired motion was requested. The mentioned program was also used to measure the motion of the shoulder abduction, with the participant sitting, with the upper limbs in an anatomical position, and the device was positioned in the distal and anterior region of the forearm. Finally, the strength test was applied in the superior trapezius muscle using the principles of the Oxford scale ${ }^{19}$.

In a first moment, group A received the EB application, according to the Application Manual ${ }^{8}$. The participants of group B, in this first moment, received the application of the same described technique, but with the medical tape. At the end of the class and on the following day, all the volunteers were reassessed according to the same procedures of the evaluation. Two weeks after the first application, group A received the application with medical tape, and group B the EB, in the same way as in the first moment, and they were reassessed. It is worth mentioning that the participants were not aware of which material was being applied, they were only informed that a tape was being placed in the region.

This study was approved by the Ethics Committee of the Pontifícia Universidade Católica do Paraná, under opinion number 987.607, and follows the Resolution 466/12 of the National Health Council.

\section{Statistical analysis}

The data was tabulated and then statistically handled using the software SPSS 20.0. The normality of the variables was tested using the Shapiro-Wilk test. For the intragroup comparisons, the Friedman test was used when the data was not within the normality standards, and the ANOVA test was used for variables with data normality. The post-significance tests used were Wilcoxon and Tukey HSD. The comparison between groups A and $B$ was performed after the calculation of the differences between the three evaluation moments (pre-post, pre with 24 hours after; post with 24h). For the comparison between the groups, the Mann-Whitney test was used (non-normal distribution of data) and $\mathrm{t}$-Student for independent samples (normal distribution of data). The value of $p$ equal to or lower than 0.05 was adopted for the statistical significance. 


\section{RESULTS}

The sample was composed of 16 participants. In the demographic data of the studied population, the statistical difference between the groups was only found in the weight $(\mathrm{p}=0.04)$. All the participants were right-handedness and presented a taut band or TP on that side. Table 1 shows that group A significantly reduced the pain (McGill and NS). In the post-significance test, the McGill variable showed a statistically significant difference between the initial evaluation and post-application $(\mathrm{p}=0.04)$ and between the initial evaluation and post-24h ( $\mathrm{p}=0.03)$ in the first application, using the EB. In the second application, with the medical tape, there was a reduction of pain between the initial evaluation and post-24h ( $\mathrm{p}=0.03)$.

The NS showed a statistically significant difference between the initial evaluation and post-application $(\mathrm{p}=0.01)$ and between the initial evaluation and post-24h ( $\mathrm{p}=0.01)$ in the first application (EB). In the second application, with the medical tape, there was a pain reduction between the initial evaluation and the post-application evaluation $(\mathrm{p}=0.04)$, and between the initial evaluation and after $24 \mathrm{~h}(\mathrm{p}=0.04)$.

In the detection of the TP and the taut band tension in the three evaluation moments, the taut band tension decreased compared to the initial evaluation; however, the TP was present in the post-application and the post-24h evaluations in all the participants.

Another issue raised by the participants was the sensation that the pain increased in the member contralateral to the application. It is worth noting that two participants reported that the application of the medical tape was more effective, while the rest of the group did not express a preference.

In the comparison of the three evaluation moments in group $\mathrm{B}$, there was also a statistically significant reduction of pain (McGill and NS) (Table 2). The McGill variable showed a statistically significant difference between the initial evaluation and post-24h $(\mathrm{p}=0.02)$ and between the post-application evaluation and post- $24 \mathrm{~h}(\mathrm{p}=0.02)$ in the first care, using the medical tape. In the second application with the EB, the difference was between the initial evaluation and the post-24h ( $\mathrm{p}=0.03)$.

The NS showed a significant difference between the first evaluation and post-24h ( $\mathrm{p}=0.01)$ in the first application (medical tape). The second application (EB) also showed a difference between the initial evaluation and the post-application ( $\mathrm{p}=0.04)$, and between the initial evaluation and after $24 \mathrm{~h}(\mathrm{p}=0.03)$.

A result similar to group A was found regarding the presence of TP and the taut band after the application. Regarding the participant's perception, four of them stated that the medical tape provided a more effective and faster result. In contrast, two preferred the EB.

Table 3 shows the mean of the differences of the comparison between the evaluation moments for groups A and B. In the first application, where group A received EB and group B the medical tape, a statistically significant difference was found in the lateral inclination of the cervical to the right, between the initial evaluation and post-application, and between the initial evaluation and after 24 hours. In the second application, no variable showed any difference. Group B, in the first application, presented more effective progress in the lateral inclination of the cervical to the right between the initial evaluation and post $-24 \mathrm{~h}$, and this variable receded in group $\mathrm{A}$ at the abovementioned moment.

Table 4 shows the comparison between group A and group B taking the type of application into consideration, EB or medical tape. In the application of the $\mathrm{EB}$, the variable that showed a statistically significant difference was the NS between the initial evaluation and post-application. In the medical tape application, the variables that presented a statistical difference was the goniometry of the lateral inclination of the cervical to the right between the initial evaluation and post-application, and between the initial and post- $24 \mathrm{~h}$, and goniometry of the lateral inclination of the cervical to the left between the initial evaluation and post-application.

One can note that both in the EB moment and the medical tape, group A showed a higher pain reduction (McGill and NS) than group B.

Table 1. Evaluation of pain and goniometry of group $A(n=8)$

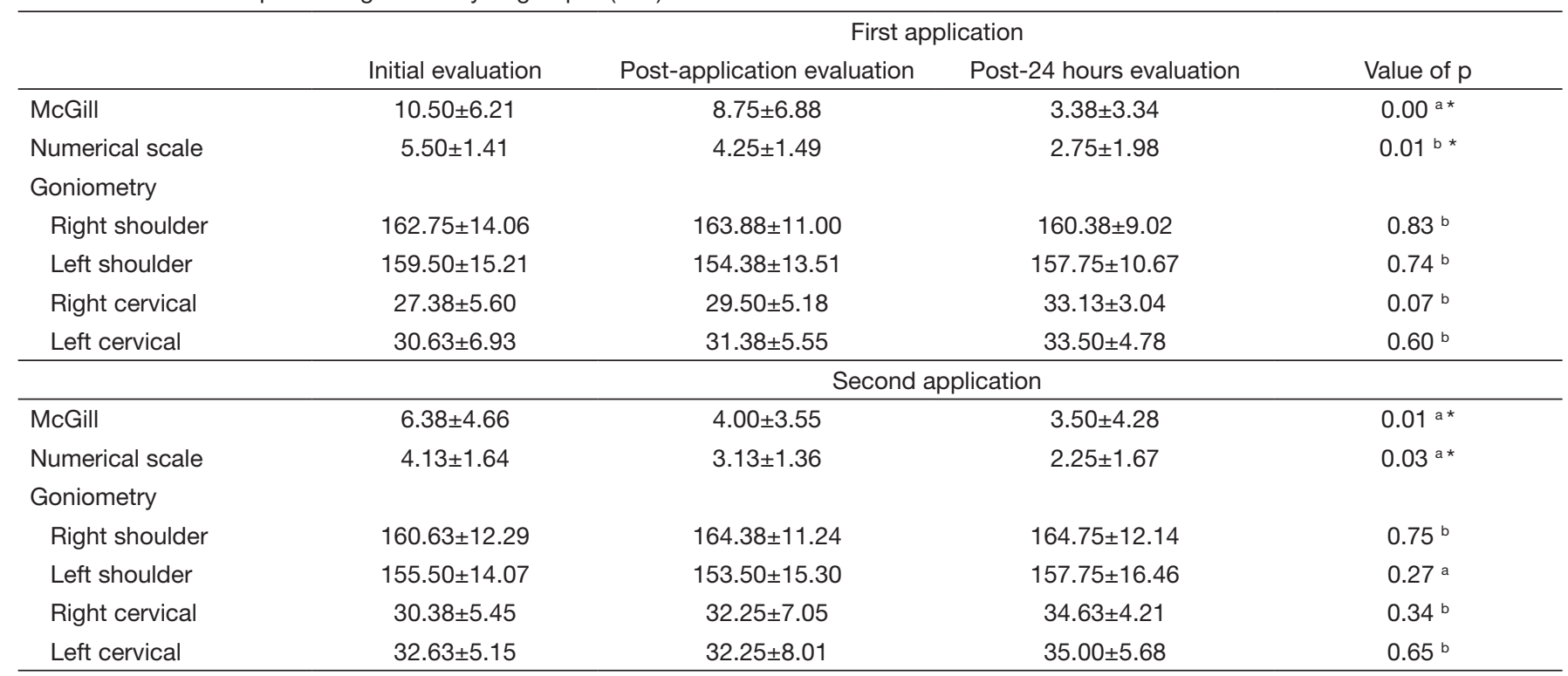

Source: research data.

a Friedman; ${ }^{\text {b }}$ ANOVA; * $p<0.05$. 
Table 2. Evaluation of pain and goniometry of group $B(n=8)$

\begin{tabular}{|c|c|c|c|c|}
\hline & \multicolumn{4}{|c|}{ First application } \\
\hline & Initial evaluation & Post-application evaluation & Post-24 hours evaluation & Value of $p$ \\
\hline McGill & $10.50 \pm 6.21$ & $8.75 \pm 6.88$ & $3.38 \pm 3.34$ & $0.00 a^{a}$ \\
\hline \multicolumn{5}{|l|}{ Goniometry } \\
\hline Right shoulder & $162.75 \pm 14.06$ & $163.88 \pm 11.00$ & $160.38 \pm 9.02$ & $0.83^{b}$ \\
\hline Right cervical & $27.38 \pm 5.60$ & $29.50 \pm 5.18$ & $33.13 \pm 3.04$ & $0.07^{b}$ \\
\hline \multirow[t]{2}{*}{ Left cervical } & $30.63 \pm 6.93$ & $31.38 \pm 5.55$ & $33.50 \pm 4.78$ & $0.60^{b}$ \\
\hline & \multicolumn{4}{|c|}{ Second application } \\
\hline McGill & $6.38 \pm 4.66$ & $4.00 \pm 3.55$ & $3.50 \pm 4.28$ & $0.011^{a *}$ \\
\hline \multicolumn{5}{|l|}{ Goniometry } \\
\hline Left shoulder & $155.50 \pm 14.07$ & $153.50 \pm 15.30$ & $157.75 \pm 16.46$ & $0.27^{a}$ \\
\hline Right cervical & $30.38 \pm 5.45$ & $32.25 \pm 7.05$ & $34.63 \pm 4.21$ & $0.34^{b}$ \\
\hline Left cervical & $32.63 \pm 5.15$ & $32.25 \pm 8.01$ & $35.00 \pm 5.68$ & $0.65^{b}$ \\
\hline
\end{tabular}

Source: research data.

a Friedman; ${ }^{\text {b }}$ ANOVA; * $\mathrm{p}<0.05$.

Table 3. Intergroup Evaluation - comparison of the differences between groups A and B in the two moments of application

\begin{tabular}{|c|c|c|c|c|c|c|c|c|c|c|}
\hline & \multirow[t]{2}{*}{ Evaluations } & \multicolumn{3}{|c|}{ Difference after with the initial } & \multicolumn{3}{|c|}{ Difference $24 \mathrm{~h}$ with the initial } & \multicolumn{3}{|c|}{ Post-24 hours difference } \\
\hline & & Group A & Group B & $\begin{array}{l}\text { Value } \\
\text { of } p\end{array}$ & Group A & Group B & Value of $p$ & Group A & Group B & $\begin{array}{l}\text { Value } \\
\text { of } p\end{array}$ \\
\hline \multirow{3}{*}{ 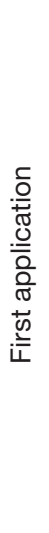 } & $\begin{array}{l}\text { Numerical } \\
\text { scale }\end{array}$ & $-2.12 \pm 0.83$ & $-1.25 \pm 1.04$ & $0.08^{b}$ & $-3.25 \pm 1.83$ & $-2.75 \pm 2.05$ & $0.62^{b}$ & $-1.125 \pm 2.17$ & $-1.50 \pm 2.14$ & $0.73^{b}$ \\
\hline & $\begin{array}{l}\text { Abduction } \\
\text { of the left } \\
\text { shoulder }\end{array}$ & $2.12 \pm 11.33$ & $-5.125 \pm 8.43$ & $0.17^{b}$ & $-0.5 \pm 14.05$ & $-1.75 \pm 8.28$ & $0.83^{b}$ & $-0.5 \pm 14.05$ & $-1.75 \pm 8.28$ & $0.83^{b}$ \\
\hline & $\begin{array}{l}\text { Right lateral } \\
\text { inclination }\end{array}$ & $4.00 \pm 4.96$ & $-2.5 \pm 3.55$ & $0.01^{a}$ * & $1.50 \pm 5.07$ & $-6.5 \pm 6.97$ & $0.02^{b *}$ & $-2.5 \pm 3.55$ & $-4.00 \pm 4.96$ & $0.28^{a}$ \\
\hline \multirow{4}{*}{ 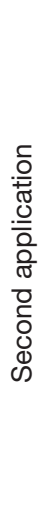 } & $\begin{array}{l}\text { Numerical } \\
\text { scale }\end{array}$ & $-2.75 \pm 2.43$ & $-1.00 \pm 1.07$ & $0.09^{b}$ & $-2.75 \pm 3.11$ & $-1.88 \pm 1.89$ & $0.51^{b}$ & $0.00 \pm 1.77$ & $-0.88 \pm 1.25$ & $0.35^{a}$ \\
\hline & $\begin{array}{l}\text { Abduction } \\
\text { of the right } \\
\text { shoulder }\end{array}$ & $5.88 \pm 14.11$ & $3.75 \pm 8.21$ & $0.92^{a}$ & $7.75 \pm 10.51$ & $4.13 \pm 8.46$ & $0.46^{b}$ & $1.88 \pm 11.70$ & $0.38 \pm 3.25$ & $0.92^{a}$ \\
\hline & $\begin{array}{l}\text { Abduction } \\
\text { of the left } \\
\text { shoulder }\end{array}$ & $2.50 \pm 12.54$ & $-2.00 \pm 10.64$ & $0.45^{b}$ & $1.50 \pm 11.66$ & $2.25 \pm 11.93$ & $0.90^{b}$ & $-1.00 \pm 8.65$ & $4.25 \pm 5.44$ & $0.17^{b}$ \\
\hline & $\begin{array}{l}\text { Right lateral } \\
\text { inclination }\end{array}$ & $2.38 \pm 2.97$ & $1.88 \pm 6.56$ & $0.53^{a}$ & $1.13 \pm 5.99$ & $4.25 \pm 3.01$ & $0.21^{b}$ & $-1.25 \pm 5.31$ & $2.38 \pm 5.53$ & $0.34^{a}$ \\
\hline
\end{tabular}

Source: research data.

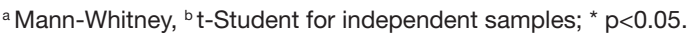


Table 4. Intergroup evaluation - comparison of the differences between groups A and B for the application of the elastic bandage and medical tape

\begin{tabular}{|c|c|c|c|c|c|c|c|c|c|c|}
\hline & \multirow[t]{2}{*}{ Evaluations } & \multicolumn{3}{|c|}{ Difference after with the initial } & \multicolumn{3}{|c|}{ Difference $24 \mathrm{~h}$ with the initial } & \multicolumn{3}{|c|}{ Post-24 hours difference } \\
\hline & & Group A & Group B & $\begin{array}{l}\text { Value } \\
\text { of } p\end{array}$ & Group A & Group B & $\begin{array}{l}\text { Value } \\
\text { of } p\end{array}$ & Group A & Group B & $\begin{array}{l}\text { Value } \\
\text { of } p\end{array}$ \\
\hline \multirow{5}{*}{ 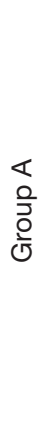 } & Numerical scale & $-2.12 \pm 0.83$ & $-1.00 \pm 1.07$ & $0.03^{b}$ * & $-3.25 \pm 1.83$ & $-1.87 \pm 1.89$ & $0.16^{b}$ & $-1.12 \pm 2.17$ & $-0.87 \pm 1.25$ & $0.78^{b}$ \\
\hline & $\begin{array}{l}\text { Abduction of the } \\
\text { right shoulder }\end{array}$ & $-1.25 \pm 8.99$ & $3.75 \pm 8.21$ & $0.26^{b}$ & $1.87 \pm 9.26$ & $4.12 \pm 8.46$ & $0.26^{b}$ & $3.13 \pm 5.67$ & $0.38 \pm 3.25$ & $0.25^{b}$ \\
\hline & $\begin{array}{l}\text { Abduction of the } \\
\text { left shoulder }\end{array}$ & $2.12 \pm 11.33$ & $-2.00 \pm 10.64$ & $0.46^{b}$ & $-0.50 \pm 14.05$ & $2.25 \pm 11.93$ & $0.67^{b}$ & $-0.50 \pm 14.05$ & $4.25 \pm 5.44$ & $0.39 \mathrm{~b}$ \\
\hline & $\begin{array}{l}\text { Right lateral } \\
\text { inclination }\end{array}$ & $4.00 \pm 4.96$ & $1.87 \pm 6.56$ & $0.48^{b}$ & $1.50 \pm 5.07$ & $4.25 \pm 3.01$ & $0.21^{b}$ & $-2.50 \pm 3.55$ & $2.38 \pm 553$ & $0.07^{a}$ \\
\hline & $\begin{array}{l}\text { Left lateral } \\
\text { inclination }\end{array}$ & $1.63 \pm 3.25$ & $-0.37 \pm 4.21$ & $0.31^{b}$ & $0.12 \pm 5.03$ & $2.38 \pm 3.16$ & $0.42^{a}$ & $-1.50 \pm 6.52$ & $2.75 \pm 4.40$ & $0.28^{a}$ \\
\hline \multirow{6}{*}{ 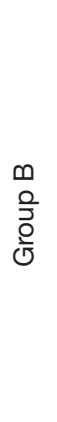 } & McGill & $-5.25 \pm 6.41$ & $-1.75 \pm 2.49$ & $0.23^{a}$ & $-7.25 \pm 7.01$ & $-7.13 \pm 6.88$ & $0.97^{b}$ & $-2.00 \pm 4.56$ & $-5.38 \pm 7.58$ & $0.19^{a}$ \\
\hline & Numerical scale & $-2.75 \pm 2.43$ & $-1.25 \pm 1.04$ & $0.14^{\mathrm{b}}$ & $-2.75 \pm 3.11$ & $-2.75 \pm 2.05$ & $1.00^{b}$ & $0.00 \pm 1.77$ & $-1.50 \pm 2.14$ & $0.17^{a}$ \\
\hline & $\begin{array}{l}\text { Abduction of the } \\
\text { right shoulder }\end{array}$ & $5.88 \pm 14.11$ & $1.13 \pm 8.29$ & $0.66^{a}$ & $7.75 \pm 10.51$ & $-2.38 \pm 10.29$ & $0.07^{b}$ & $1.88 \pm 4.00$ & $-3.50 \pm 8.33$ & $0.29^{a}$ \\
\hline & $\begin{array}{l}\text { Abduction of the } \\
\text { left shoulder }\end{array}$ & $2.50 \pm 12.54$ & $-5.13 \pm 8.43$ & $0.18^{b}$ & $1.50 \pm 2.00$ & $-1.75 \pm 8.28$ & $0.53^{b}$ & $-1.00 \pm 8.65$ & $-1.75 \pm 8.28$ & $0.86^{b}$ \\
\hline & $\begin{array}{l}\text { Right lateral } \\
\text { inclination }\end{array}$ & $2.38 \pm 2.97$ & $-2.50 \pm 3.55$ & $0.00^{a *}$ & $1.13 \pm 5.99$ & $-6.50 \pm 6.97$ & $0.03^{b *}$ & $-1.25 \pm 5.31$ & $-4.00 \pm 4.96$ & $0.30^{b}$ \\
\hline & $\begin{array}{l}\text { Left lateral } \\
\text { inclination }\end{array}$ & $-1.88 \pm 2.10$ & $1.63 \pm 3.25$ & $0.03^{a *}$ & $1.00 \pm 2.39$ & $0.13 \pm 5.03$ & $1.00^{a}$ & $2.88 \pm 2.23$ & $-1.50 \pm 6.52$ & $0.06^{a}$ \\
\hline
\end{tabular}

Source: research data.

a Mann-Whitney, ${ }^{\text {b } t-S t u d e n t ~ f o r ~ i n d e p e n d e n t ~ s a m p l e s ; ~}{ }^{*} \mathrm{p}<0.05$.

\section{DISCUSSION}

The results showed that the EB and the medical tape reduce the pain (McGill and NS) and there is no statistically significant difference between them.

According to the theory proposed by Simons, the region around the TP is in an ischemic condition, resulting in lack of oxygen and glucose for the metabolism. After the TP relaxation, the blood flow to the tissue is activated, allowing the oxygen perfusion so that the skeletal muscle may recover the homeostasis ${ }^{20,21}$. The mechanism of action of the EB correlates to this theory due to the fact the it lifts the subcutaneous space, which would lead to the increase of the circulation and the removal of the heat produced by the inflammation. And due to the reduction of pressure on the nociceptors, the sensation of pain would diminish ${ }^{2}$.

The afferent stimulation, which is promoted both by the EB and the medical tape application, may be cited as another mechanism of action. According to the Gate Control Theory by Melzack and Wall, the velocity of the proprioceptive stimulus is higher, thus inhibiting the transmission of nociceptive signs at the spinal level in chronic musculoskeletal pain situations, leading to the attenuation of the pain experience ${ }^{11,22-24}$.

A similar result was found with the application of the EB in patients with latent TP in the sternocleidomastoid muscle, with a pain reduction and increase of the range of motion of the joint when compared to the group control, which did not receive care ${ }^{1}$.
To lift the subcutaneous space, improve the blood circulation, and consequently reduce pain, the BE must be applied with the elongated muscle to generate circumvolutions ${ }^{14}$. However, a study obtained a similar reduction in the intensity of pain and disability in patients treated according to the treatment manual of the Kinesiotaping Method and those who received the EB application without tension, and not creating circumvolutions $s^{15}$.

Once again, comparing the EB with and without tension, the statistically significant difference only existed up to the third day, indicating that the potential benefits of the bandage application are immediate. No differences were found between the groups regarding the measurement of pain and disability ${ }^{13}$.

These studies supported the results found since in the medical tape application, the circumvolutions were not generated, and both materials significantly reduced the pain (McGill and NS), referring this fact to the exteroceptive effect.

Regarding the range of motion of the joint, the muscle with the TP is stiff, with shortened sarcomeres, leading to motion restriction. When the myofascial pain is treated, the muscle function should increase, the muscle fibers relax, and, therefore, the reduction of the muscle stiffness and the extension of the range of motion are expected ${ }^{25-27}$.

No statistically significant alteration was found in the range of motion in this research. This can be explained by the fact that the TP is present in all the participants after the application of the materials, although the pain sensation had decreased. 
The study had limitations as to the size of the sample, and the use of an algometer is recommended for future researches to determine the pain sensation.

\section{CONCLUSION}

The results of this study have shown that the EB application had the same effect as the medical tape application for the reduction of the pain condition and increase of the range of motion. Future studies are necessary to clarify the EB clinical effects since the mechanism of action, according to the creator of the technique, are the circumvolutions. However, they were not generated with the application of the medical tape that showed positive results.

\section{REFERENCES}

1. Bae Y. Change the myofascial pain and range of motion of the temporomandibular joint following kinesio taping of latent myofascial trigger points in the sternocleidomastoid muscle. J Phys Ther Sci. 2014;26(9):1321-4.

2. Wu WT, Hong CZ, Chou LW. The kinesio taping method for myofascial pain control. Evid Based Complement Alternat Med. 2015;2015:950519.

3. Cardoso JP, Araújo TM, Carvalho FM, Oliveira NF, Reis EJ. [Psychosocial work-related factors and Musculoskeletal pain among schoolteachers]. Cad Saude Publica. 2011;27(8):1498-506. Portuguese.

4. Erick PN, Smith DR. A systematic review of musculoskeletal disorders among school teachers. BMC Musculoskeletal Disord. 2011;12(260):1-11.

5. Jung-Ho L, Min-Sik Y, Bong-Jun K, Jin-Sang K. The effect of stabilization exercises combined with taping therapy on pain and function of patients with myofascial pain syndrome. J Phys Ther Sci. 2012;24(12):1283-7.

6. Luz Júnior MA, Sousa MV, Neves LA, Cezar AA, Costa, LO. Kinesio Taping is not better than placebo in reducing pain and disability in patients with chronic non-specific low back pain: a randomized controlled trial. Braz J Phys Ther. 2015;19(6):482-90.

7. González-Iglesias J, Fernández-de-Las-Peñas C, Cleland JA, Huijbregts P, Del Rosario Gutierrez-Vega M. Short-term effects of cervical kinesio taping on pain and cervical range of motion in patients with acute whiplash injury: a randomized clinical trial. J Orthop Sports Phys Ther. 2009;39(7):515-21.

8. Sijmonsma J. TNM Manual da Banda Neuromuscular. Portugal: Aneid Press; 2000.

9. Taylor RL, O'Brien L, Brown T. A scoping review of the use of elastic therapeutic tape for neck or upper extremity conditions. J Hand Ther. 2014;27(3):235-46.

10. Castro-Sánchez AM, Lara-Palomo IC, Matarán-Peñarrocha GA, Fernández-Sánchez M, Sánchez-Labraca N, Arroyo-Morales M. Kinesio Taping reduces disability and pain slightly in chronic non-specific low back pain: a randomised trial. J Physiother.
2012;58(2):89-95

11. Kachanathu SJ, Alenazi AM, Seif HE, Hafez AR, Alroumim MA. Comparison between Kinesio Taping and a Traditional Physical Therapy program in treatment of nonspecific low back pain. J Phys Ther Sci. 2014;26(8):1185-8.

12. Paoloni M, Bernetti A, Fratocchi G, Mangone M, Parrinello L, Del Pilar Cooper M, et al. Kinesio Taping applied to lumbar muscles influences clinical and electromyographic characteristics in chronic low back pain patients. Eur J Phys Rehabil Med. 2011;47(2):237-44.

13. Thelen MD, Dauber JA, Stoneman PD. The clinical efficacy of kinesiotape for shoulder pain: a randomized, double-blinded, clinical trial. J Orthop Sports Phys Ther. 2008:38(7):389-95.

14. Montalvo AM, Cara EL, Myer GD. Effect of kinesiology taping on pain in individuals with musculoskeletal injuries: systematic review and meta-analysis. Phys Sportsmed. 2014; $42(2): 48-57$

15. Parreira Pdo C, Costa Lda C, Takahashi R, Hespanhol Junior LC, Luz Junior MA, Silva TM, et al. Kinesio taping to generate skin convolutions is not better than sham taping for people with chronic non-specific low back pain: a randomised trial. J Physiother. 2014;60(2):90-6.

16. Kalron A, Bar-Sela S. A systematic review of the effectiveness of Kinesio Taping--fact or fashion? Eur J Phys Rehabil Med. 2013;49(5):699-709.

17. Ossipov MH, Dussor GO, Porreca F. Central modulation of pain. J Clin Invest. 2010;120(11):3779-87.

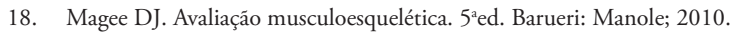

19. Kendall FP, McCreary EK, Provance PG, Rodgers M, Romani WI. Músculos: provas e funçôes. $5^{\mathrm{a}} \mathrm{ed}$. São Paulo: Manole; 2007.

20. Moraska AF, Hickner RC, Kohrt WM, Brewer A. Changes in blood flow and cellular metabolism at a myofascial trigger point with trigger point release (ischemic compression): a proof-of-principle pilot study. Arch Phys Med Rehabil. 2013;94(1):196-200.

21. Zhang Y, Ge HY, Yue SW, Kimura Y, Arendt-Nielsen L. Attenuated skin blood flow response to nociceptive stimulation of latent myofascial trigger points. Arch Phys Med Rehabil. 2009;90(2):325-32.

22. Lim EC, Tay MG. Kinesio taping in musculoskeletal pain and disability that lasts for more than 4 weeks: is it time to peel off the tape and throw it out with the sweat? A systematic review with meta-analysis focused on pain and also methods of tape application. Br J Sports Med. 2015;49(24):1558-66.

23. Saavedra-Hernández M, Castro-Sánchez AM, Arroyo-Morales M, Cleland JA, Lara-Palomo IC, Fernández-de-las-Penas C. Short term effects of kinesiotaping versus cervical thrust manipulation in patients with mechanical neck pain: a randomized clinical trial. J Orthop Sports Phys Ther. 2012;42(8):724-30.

24. Artioli DP, Bertolini GR. Kinesio Taping: aplicação e seus resultados sobre a dor. Fisioter Pesq. 2014;21(1):94-9.

25. Ge HY, Arendt-Nielsen L. Latent myofascial trigger points. Curr Pain Headache Rep. 2011;15(5):386-92.

26. Lee SH, Chen CC, Lee CS, Lin TC, Chan RC. Effects of needle electrical intramuscular stimulation on shoulder and cervical myofascial pain syndrome and microcirculation. J Chin Med Assoc. 2008;71(4):200-6.

27. Aranha MF, Müller CE, Gaviāo MB. Pain intensity and cervical range of motion in women with myofascial pain treated with acupuncture and electroacupuncture: a double-blinded, randomized clinical trial. Braz J Phys Ther. 2015;19(1):34-43. 